\title{
Toxic Effects of Heavy Metals on the Growth and Phosphorus Removal Efficiency of Phosphorus Accumulating Microorganisms (PAOs)
}

Da Hee Sin, Deok Hyeon Kim, Jong In Kim, Moon-Soon Lee ${ }^{1}$, and Keun-Yook Chung*

Department of Environmental and Biological Chemistry, Chungbuk National University, Cheongju 361-763, Korea

${ }^{1}$ Department of Industrial Plants, Chungbuk National University, Cheongju 361-763, Korea

(Received: November 15 2013, Accepted: December 17 2013)

Phosphorus accumulating microorganisms (PAOs) are influenced by various environmental factors and heavy metals. This study was performed to evaluate the effects of the selected heavy metals on the growth and phosphorus removal capacity of Bacillus sp. 3434 BRRJ, Pseudomonas aerunogisa, and Bacillus Subtilis, well known as PAOs. The heavy metals used in this study included $\mathrm{Cu}, \mathrm{Cd}$, $\mathrm{As}$, and $\mathrm{Zn}$. The $\mathrm{IC}_{50}$ (median inhibition concentration) values of Bacillus sp. 3434 BRRJ for the $\mathrm{Cu}, \mathrm{Cd}$, As, and $\mathrm{Zn}$ were $8.07 \mathrm{mg} \mathrm{L}^{-1}, 0.18 \mathrm{mg} \mathrm{L}^{-1}$, $73.62 \mathrm{mg} \mathrm{L}^{-1}$ and $0.25 \mathrm{mg} \mathrm{L}^{-1}$, respectively. The $\mathrm{IC}_{50}$ values of Pseudomonas aerunogisa for the $\mathrm{Cu}, \mathrm{Cd}, \mathrm{As}$, and $\mathrm{Zn}$ were $4.45 \mathrm{mg} \mathrm{L}^{-1}, 0.16 \mathrm{mg} \mathrm{L}^{-1}, 18.51 \mathrm{mg} \mathrm{L}^{-1}$ and $2.34 \mathrm{mg} \mathrm{L}^{-1}$, respectively. The $\mathrm{IC}_{50}$ values of Bacillus Subtilis for the $\mathrm{Cu}, \mathrm{Cd}$, As, and $\mathrm{Zn}$ were $3.81 \mathrm{mg} \mathrm{L}^{-1}, 0.18 \mathrm{mg} \mathrm{L}^{-1}, 11.31 \mathrm{mg} \mathrm{L}^{-1}$ and $0.47 \mathrm{mg} \mathrm{L}^{-1}$, respectively. The phosphorus removal efficiencies of the three bacteria, Bacillus sp. 3434 BRRJ, Pseudomonas aerunogisa, and Bacillus subtilis were $93.12 \%, 71.81 \%$, and $65.31 \%$, respectively. Based on the results of the three PAOs obtained from the study, it appears that Bacillus sp. 3434BRRJ may have the best results in terms of their growth rate and $P$ removal efficiencies.

Key words: Bacillus sp. 3434BRRJ, Pseudomonas aerunogisa, Bacillus subtilis PAOs, Growth, Phosphorus removal efficiency, Heavy metals, $\mathrm{IC}_{50}$

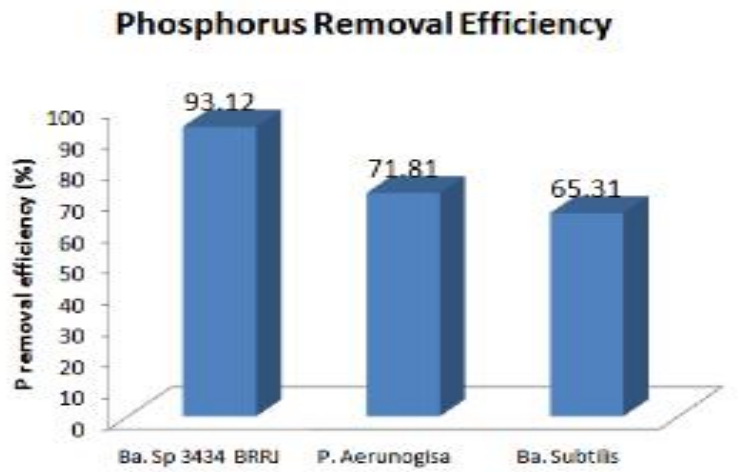

Comparison of phosphorus removal efficiencies by three bactera used in this study.

*Corresponding author : Phone: +82432613383, Fax: +82432715921, E-mail: kychung@cbnu.ac.kr

${ }^{\S}$ Acknowledgement: This work was supported by the research grant of Chungbuk National University in 2012. 


\section{Introduction}

물의 자연적인 정화능력을 초과하는 오염 물질이 천연의 자연수역에 인위적으로 배출되면 수질오염이 일어난다. 수 질오염물질에는 중금속류와 그 화합물, 유기물질, 부유물 질, 세제, 산 및 알칼리류 등이 있는데, 특히 하수와 폐수에 포함된 질소와 인은 조류와 수서 식물의 생장을 촉진하는 제한 영양물질로 작용하기 때문에 간접적인 오염원이 된다. 조류와 수서 식물이 모두 호흡하는 야간이 되면 높은 산소 요구를 나타내어 부영양화 현상이 일어나는데 이는 어류와 다른 수서 생물에 악영향을 미치게 되며 식수원 등의 유용 한 목적으로의 사용에도 부정적인 영향을 미친다 (Gabriel Bitton, 1999). 특히 인은 지표수 부영양화의 주요인이므로 지표수로 방류수를 내보내기 전에 폐수 처리 공정에 의해 제거 되어야 한다. 폐수 내의 총인의 농도는 평균 10 20 $\mathrm{mg} \mathrm{L}^{-1}$ 이다. 대부분 합성세제의 인산염으로부터 나오며, 정 인산염, 다중인산염, 유기인의 형태로 존재하며 대부분이 정인산염 $\left(\mathrm{PO}_{4}^{3-}\right)$ 형태이다 (Meganck and Faup, 1988).

또한 산업화가 진행됨에 따라 발생하는 산업폐수 중에는 환경오염물질이 다량 포함되어 있다. 특히 중금속은 인축에 유해한 영향을 끼치며, 생물 농축의 과정을 거쳐 먹이 사슬 에 상위에 있는 인간에게 크게 악영향을 끼칠 수 있다. 또한 독성물질이 생물학적 하폐수처리장에 유입되면 박테리아를 비롯한 미생물의 활성도를 저해하여 유기물 및 영양염류처 리 효율과 침전효율이 저하되며 농축특성을 악화시키기도 한다. 특히 구리, 수은, 납, 니켈, 카드뮴, 비소는 생물체에 유해한 대표적인 중금속 물질로 알려져 있다. 폐수 내의 중 금속을 제거하기 위해서 다방면으로 연구가 이루어지고 있 다 (Hammaini et al. 2007; Choi et al. 2009). 생물학적 인 제거 공정 내의 PAOs에 대한 중금속의 독성효과를 평가하 기위해 이에 대한 연구 또한 진행되고 있다 (Boswell et al. 1999; Chung et al. 2006; Wang et al. 2011).

이런 수질 오염 물질 중 인을 제거하는 데에는 물리·화학 적 침전법, 미생물 중개 화학적 침전법, 폐수 미생물에 의한 인 동화, 미생물에 의한 다중인산염 축적 등 다양한 기작들 이 이용되고 있다 (Arbin, 1985). 물리·화학적 침전법은 안 정적이기는 하나 비용이 많이 들거나 슬러지가 과다 생산되 는 등의 단점을 가지고 있다 (U.S. EPS, 1987). 한편 미생물 을 이용한 생물학적 인 제거는 장기적인 관점에서 안정적이고 경제적으로 여러 가지 장점을 가지고 있다. 생물학적 인 제거 방법은 PAOs (Phosphorus accumulating microorganisms)에 속하는 미생물을 이용하는 방법이다. PAOs에 속하는 미생 물은 혐기성 조건에서 다중인산염을 가수분해하여 얻은 에 너지로 탄소기질을 흡수하여 PHB (poly- $\beta$-hydrobutyrate) 로 저장하며 그 과정에서 무기인을 방출한다. 반면 호기성 조건에서는 외부 탄소원을 대사에 이용하며 대사로부터 나
온 에너지가 세포내의 다중인산염 축적에 이용된다. 단일 공정내에서 혐기성 환경과 호기성 환경을 교차시키면 미생 물에 인염 과다 축적이 유발되어 인을 제거 할 수 있게 된다 (Comeau et al., 1986). 그러나 어떤 기작에 의해 인이 제거 되는지 명확하게 규명되지 않았기 때문에 최적 환경 조건을 개발하지 못하고 있는 실정이다 (Mino et al,, 1988).

본 연구는 PAOs에 속하는 폐수분리 미생물 Bacillus $s p$. 3434 BRRJ, Pseudomonas aeruginosa, Bacillus subtilis를 이용하여 인을 제거하는 공정에서 중금속을 함유한 폐수에 현장 적용성을 확인하고자 수행되었다. 따라서 호기성 조건 하에서 미생물의 인 축적 능력의 평가 및 대표적인 유해 중 금속 $(\mathrm{Cu}, \mathrm{As}, \mathrm{Cd}, \mathrm{Zn})$ 에 대한 독성효과를 평가하였다.

\section{Materials and Methods}

미생물의 분리 및 동정 본 연구에서 사용한 Bacillus sp. $3434 B R R J$ 균주는 대전에 위치한 폐수처리장에서 채수 한 폐수에서 미생물을 분리하여 이용하였다. 폐수처리장에 서 채수한 폐수 $5 \mathrm{~mL}$ 를 $0.22 \mu \mathrm{m}$ pore size의 membrance filter로 감압 여과하고 멸균된 증류수로 씻어낸 후 여액은 버리고 filter에 남은 균체에 멸균 증류수 $5 \mathrm{~mL}$ 을 넣고 균체 를 모은 후 그 액을 $200 \mathrm{~mL}$ 의 실험배지가 들어 있는 $250 \mathrm{ml}$ 삼각플라스크에 $2 \mathrm{~mL}$ 접종하여 48 시간 동안 진탕배양 $\left(30^{\circ} \mathrm{C}\right.$, $150 \mathrm{rpm}$ )하였다. 여기서 얻어진 3가지 종의 미생물 중 인 제거능이 가장 높다고 판단되는 종을 선별하여 동정하였다. Bacillus subtilis, Pseudomonas aeruginosa 미생물은 한국 생명공학연구원 생물자원센터에서 분양받은 미생물을 이용 하였다. 동결 건조된 분양 미생물을 medium에 백금이로 적 당량을 접종한 후 이틀간 배양하여 활성화 시킨 후 Agar plate에 미생물을 배양하였다.

생장 및 인 제거에 대한 환경인자의 영향 미생물의 생장 및 인 제거에 영향을 줄 수 있는 여러 가지 환경인자를 모의 실험을 통하여 환경조건을 온도 $30^{\circ} \mathrm{C}, \mathrm{pH}$ 7로 고정하 였다. 그리고 탄소원으로 Glucose를 사용하여 하였다.

미생물의 배양 및 생육도 측정 변형한 Zafiri 배지를 사용하여 미생물을 배양하였다 (Zafiri, 1995). 실험배지에 사용된 Solution은 Basic medium solution에 phosphate solution 1,000 $\mathrm{mg} \mathrm{L}^{-1}, 1 \mathrm{M}$ Tris buffer solution ( $\mathrm{pH} 7.0 \pm 0.2$ ), Trace metal solution (D.W. $\mathrm{H}_{2} \mathrm{O} 100$ mL에 $\mathrm{H}_{3} \mathrm{BO}_{3} 0.03$ g, CuSO 4 . $5 \mathrm{H}_{2} \mathrm{O} 0.1 \mathrm{~g}, \mathrm{ZnSO}_{4} \cdot 7 \mathrm{H}_{2} \mathrm{O} 0.2 \mathrm{~g}, \mathrm{MnSO}_{4}: \mathrm{H}_{2} \mathrm{O} 0.2$ g, Na2 $\mathrm{Mo}_{4}$ $2 \mathrm{H}_{2} \mathrm{O} 0.04 \mathrm{~g}$ 용해), Glucose solution 200,000 mg L ${ }^{-1}$ 을 혼 합하여 제조하였다 (Zafiri et al., 1999). 혼합된 Solution의 최종 인산의 농도가 $20 \mathrm{mg} \mathrm{L}^{-1}$ 이 되도록 조제한 후 Agar Plate에 배양된 균을 백금이로 채취하여 접종하여 진탕배양 
한다. 배양액을 채취하여 분광광도계 (SHIMADZU, UV mini1240)를 이용하여 $550 \mathrm{~nm}$ 에서 흡광도를 측정하였다. 모든 실험은 48 시간 동안 진행되었으며 6 시간 간격으로 측정하 였다.

인의 정량 배양액 중의 인 농도는 Ascorbic acid-몰리 브덴청법 (Callaway et al. 1995)에 따라 측정하였다. 배양 액을 채취하여 Membrance filter (0.20 $\mu \mathrm{m}$ pore size)로 여 과한 후 Test Tube에 여과액 $1 \mathrm{~mL}$, 증류수 $7 \mathrm{~mL}$, Ascorbic acid-molybdate 시약 $2 \mathrm{~mL}$ 을 넣은 후 $30^{\circ} \mathrm{C}$ 에서 20 분간 발 색시킨 후 분광광도계로 $880 \mathrm{~nm}$ 에서 흡광도를 측정 비교하 였다.

중금속 처리에 따른 생장 및 인 제거 실험 실험에 사용된 중금속은 구리, 카드뮴, 비소, 아연이며, 중금속과 미생물을 모두 처리하지 않은 Blank, 미생물 만을 처리한 무처리구, 중금속 만을 처리한 비교구, 미생물과 중금속을 5 개 단계별 농도로 처리한 처리구로 나누어 실험하였다. 중 금속 처리농도는 삼각플라스크에 실험배지 $195 \mathrm{~mL}$ 을 넣고 미리 액체 배양된 미생물을 처리하였을 때의 최종농도가 Bacillus sp. 3434 BRRR는 구리 2, 4, 6, 8, $10 \mathrm{mg} \mathrm{L}^{-1}$, 카드 뮴 $0.05,0.1,0.2,0.3,0.4 \mathrm{mg} \mathrm{L}^{-1}$, 아연 $0.1,0.5,1,1.5$, $2 \mathrm{mg} \mathrm{L}^{-1}$, 비소 20, 40,60, 80, $100 \mathrm{mg} \mathrm{L}^{-1}$, Pseudomonas aeruginosa와 Bacillus subtilis는 구리 1, 2, 3, 4, $5 \mathrm{mg} \mathrm{L}^{-1}$, 카드뮴 $0.05,0.1,0.2,0.3,0.4 \mathrm{mg} \mathrm{L}^{-1}$, 아연 $0.1,0.5,1$, $1.5,2 \mathrm{mg} \mathrm{L}^{-1}$, 비소 $5,10,15,20,25 \mathrm{mg} \mathrm{L}^{-1}$ 으로 처리하여 실험하였다. 생장은 분광광도계에서 $550 \mathrm{~nm}$ 로 흡광도를 측 정하여 총 48 시간동안 균의 생장이 일어나는 지점까지 6 시
간 단위로 측정하였다.

생장 저해 농도 계산 배양액의 생장률은 흡광도 값에 자연로그를 취한 값을 측정 시간별로 최소 제곱 추정에 의 한 선형 회귀식으로 계산하였다. 균의 생장이 이루어 지지 않은 초기 값은 제거하였고 균의 시간별 각 생장비율 값은 상관계수(r)값이 0.95 이상 값이 될 수 있도록 최소 5 개의 data 값을 기초로 하였다. 생장저해는 Inhibition $(\%)=(\mu$ control-uheavy metals) $\times 100 / \mu$ control 식을 이용하여 계산하였다. $\mu$ control은 각각의 중금속을 처리하지 않은 배 지에서 자란 균의 시간에 따른 생장속도를 말하며, $\mu$ heavy metals은 각각의 중금속 농도별로 처리된 배지에서 자란 균 의 시간에 따른 생장속도를 의미한다. 반 생장 농도 $\left(\mathrm{IC}_{50}\right)$ 값 을 구하기 위한 log gamma분포는 생장 저해 data를 fitting 하여 결정하였으며 log gamma분포로부터 각각의 중금속에 대한 균의 $\mathrm{I}_{50}$ 값을 계산하였다.

\section{Results}

\section{중금속에 의한 Bacillus sp. 3434 BRRJ의 생장 저해} 중금속에 의한 Bacillus $s p .3434$ BRRJ의 생장은 처리한 중 금속의 농도가 증가할수록 감소하는 경향을 $\mathrm{q}$ 보인다는 것 을 확인하였다. 구리 처리시, 무처리구와 $2 \mathrm{mg} \mathrm{L}^{-1}$ 처리구 는 12 시간 이후에 생장이 시작되었고, $4,6 \mathrm{mg} \mathrm{L}^{-1}$ 처리구는 배 양 24 시간 이후에 생장이 시작한 반면 $8 \mathrm{mg} \mathrm{L}^{-1}$ 과 $10 \mathrm{mg} \mathrm{L}^{-1}$ 에 서는 미생물의 생장이 거의 없었다 (Fig. 1(A)). 카드뮴의 경 우, 모든 처리구에서 배양 24 시간 경과 후 활발한 미생물 생장을 확인할 수 있었으며, 특히 $0.1 \mathrm{mg} \mathrm{L}^{-1}$ 과 $0.2 \mathrm{mg} \mathrm{L}^{-1}$
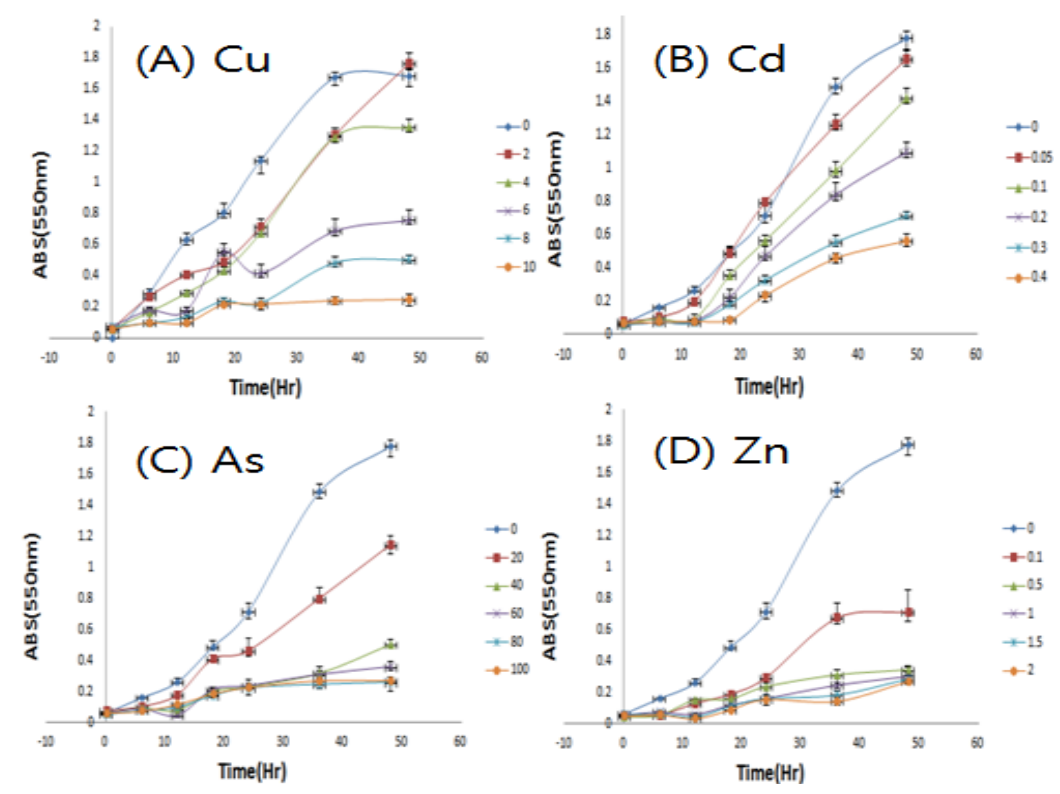

Fig. 1. Growth of Bacillus sp. 3434 BRRJ as a function of time in relation to heavy metal concentrations : (A) Copper; (B) Cadmium; (C) Arsenic; (D) Zinc. 
처리구는 급격한 생장이 이루어졌다 (Fig. 1(B)). 비소는 무 처리구와 최저농도 중금속 처리구 간의 차이가 거의 없었던 앞의 두 중금속들에 비해 무처리구와 최저농도 처리구에서 생장의 차이가 뚜렷하였으며 $60 \mathrm{mg} \mathrm{L}^{-1}$ 이상의 비소 처리구 는 미생물의 생장이 매우 적었다 (Fig. 1(C)). 아연의 경우, 미생물 생장이 무처리구와 $0.1 \mathrm{mg} \mathrm{L}^{-1}$ 사이의 격차가 크게 나타났고, $0.1 \mathrm{mg} \mathrm{L}^{-1}$ 와 $0.5 \mathrm{mg} \mathrm{L}^{-1}, 1.0 \mathrm{mg} \mathrm{L}^{-1}$ 와의 격차도 크게 나타났다 (Fig. 1(D)).

\section{중금속에 의한 Pseudomonas aeruginosa의 생장 저해}

중금속에 의한 Pseudomonas aeruginosa의 생장은 대체로 처리한 중금속의 농도가 증가할수록 크게 저해되는 것을 확 인할 수 있었다. 구리의 경우 처리 농도 차이에 대한 미생물 생장 저해가 뚜렷하였으며, 처리구와 무처리구 모두 12 시간 이전에 처리구 간 미생물 생장 차이가 나타나기 시작하였다 (Fig. 2(A)). 카드뮴 처리구에서는 12 시간이 되기 전부터 생 장곡선이 급격하게 변하였고, 처리구들간의 생장 차이가 다 른 중금속 처리에 비해 적었다 (Fig. 2(B)). 비소 처리구에 서는 최고농도로 처리한 $25 \mathrm{mg} \mathrm{L}^{-1}$ 에서도 성장을 확인할 수 있었고, 다른 처리구들 역시 무처리구와 비교하였을 때 큰 차이를 나타내지는 않고 생장곡선이 모여있는 형태를 띠었 다 (Fig. 2(C)). 아연의 경우, $2.5 \mathrm{mg} \mathrm{L}^{-1}$ 처리구를 제외한 모든 처리구에서 배양 24 시간부터 급격하게 이루어지는 미 생물의 생장을 확인할 수 있었고, $2.5 \mathrm{mg} \mathrm{L}^{-1}$ 의 경우에는 생장이 거의 일어나지 않았다 (Fig. 2(D)).

중금속에 의한 Bacillus subtilis의 생장 저해 중금속 에 의한 Bacillus subtilis의 생장 또한 앞의 두 미생물과 마
찬가지로 중금속의 농도가 증가할수록 생장이 저해된다는 결과를 얻었다. 구리 (Fig. $3(\mathrm{~A})$ )는 배양 후 24시간을 기점 으로, 24 시간 이전에는 처리구가 무처리구에 비해 생장이 빠르게 일어났으나, 24 시간 이후부터는 무처리구의 생장이 처리구에 비해 큰 것을 확인할 수 있었다. 카드뮴 (Fig. 3(B)) 의 경우, 무처리구와 최저 농도인 $0.05 \mathrm{mg} \mathrm{L}^{-1}$ 과의 미생물 생장 비교 시, 36 시간 이전까지는 무처리구와 최저농도 처 리구 간 생장의 차이가 거의 없었던 반면, 36 시간 이후부터 최저농도 처리구의 미생물 생장이 무처리구의 미생물 생장 에 비해 둔화된 것을 통해 중금속 처리구에서 무처리구에 비해 미생물 생장이 감소한 것을 확인할 수 있었다. 비소 (Fig. $3(\mathrm{C})$ )의 경우, 무처리구와 $5 \mathrm{mg} \mathrm{L}^{-1}$ 처리구의 미생물 생장이 거의 같았고, 중간 농도인 $10 \mathrm{mg} \mathrm{L}^{-1}$ 과 $15 \mathrm{mg} \mathrm{L}^{-1}$ 처 리구의 미생물 생장은 앞의 처리구들에 비해 감소하였다. 고농도인 $20 \mathrm{mg} \mathrm{L}^{-1}$ 과 $25 \mathrm{mg} \mathrm{L}^{-1}$ 처리구 간 미생물 생장은 거의 비슷하였으나, 24 시간 이후에 속도가 확연히 줄어들었 다. 아연 (Fig. 3(D))의 경우, 무처리구와 처리구간 미생물 생 장의 차이가 확연히 나타났으며, 가장 고농도인 $2.5 \mathrm{mg} \mathrm{L}^{-1}$ 에서는 약간의 생장만 확인할 수 있었다. 처리구 간 생장의 차이는 크지 않았으며 대체로 처리구의 중금속 농도가 증가 할수록 생장이 저해되었다.

미생물에 대한 중금속 처리시 반 생장농도 아래의 표는 각 미생물들에 대한 4 가지 중금속의 $\mathrm{IC}_{50}$ 값을 정리한 표로 각 중금속이 Bacillus sp. 3434 BRRJ, Pseudomonas aeruginosa, Bacillus subtilis 에 미치는 독성효과를 나타낸 다. 먼저, Bacillus $s p .3434 \mathrm{BRRJ}$ 의 생장에 가장 큰 독성 효과를 나타낸 중금속은 카드뮴이며 가장 작은 독성효과를
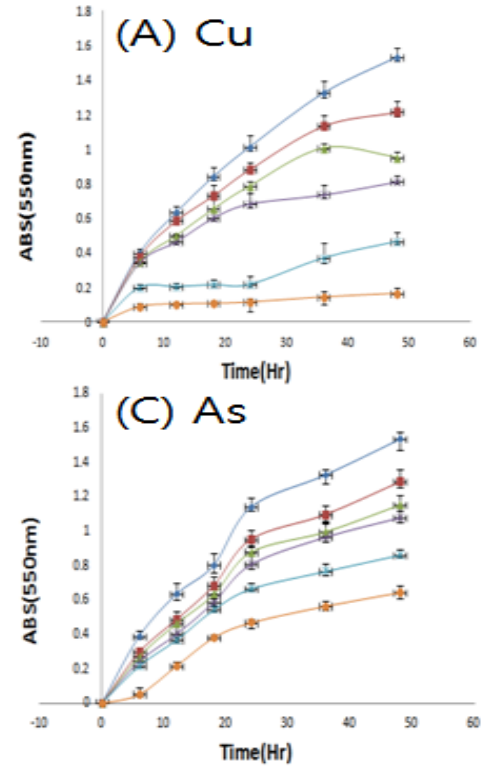

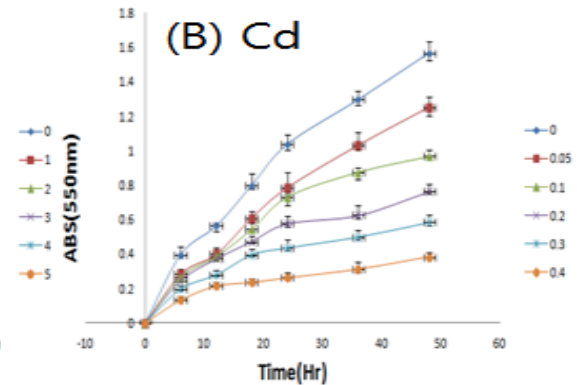

(D) $\mathrm{Zn}$

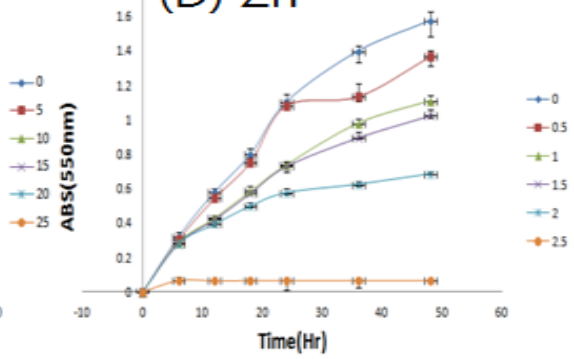

Fig 2. Growth of Pseudomonas aeruginosa as a function of time in relation to heavy metal concentrations : (A) Copper; (B) Cadmium; (C) Arsenic; (D) Zinc. 

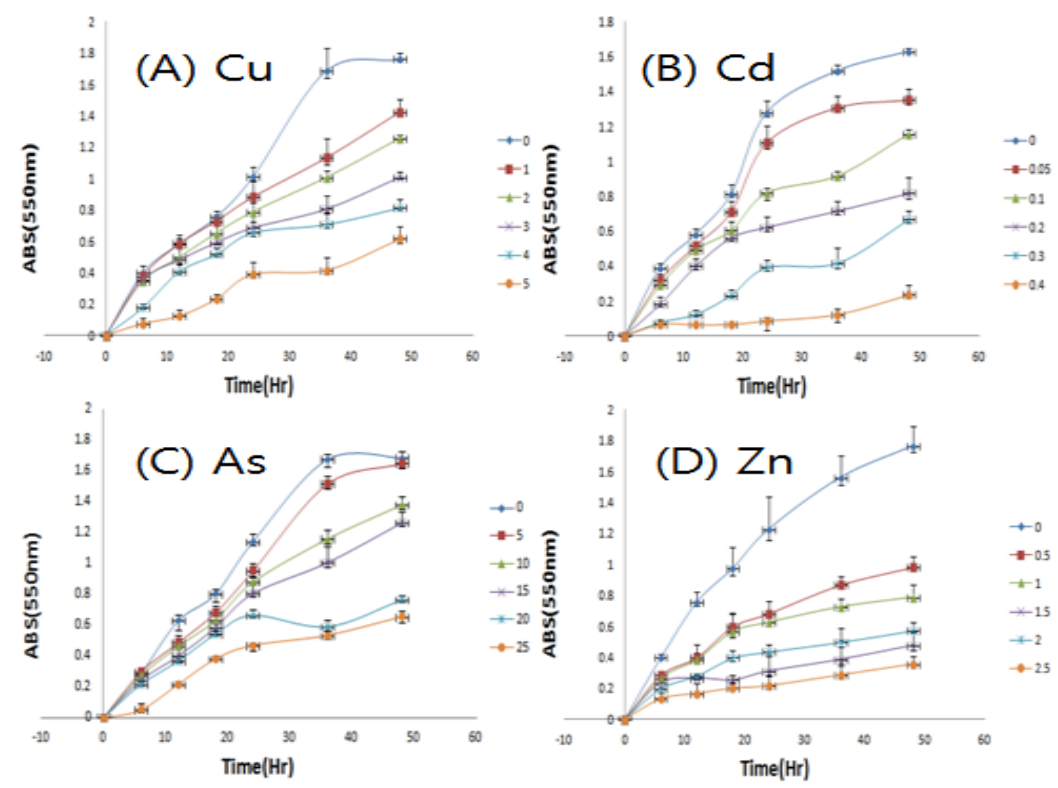

Fig. 3. Growth of Bacillus subtilis as a function of time in relation to heavy metals concentrations : (A) Copper; (B) Cadmium; (C) Arsenic; (D) Zinc.

보인 중금속은 비소인 것을 확인할 수 있었으며, 중금속으 로 인한 Bacillus sp. $3434 \mathrm{BRRJ}$ 의 $\mathrm{IC}_{50}$ 은 $\mathrm{Cu} 8.07 \mathrm{mg} \mathrm{L}^{-1}$, Cd $0.18 \mathrm{mg} \mathrm{L}^{-1}$, As $73.62 \mathrm{mg} \mathrm{L}^{-1}$, Zn $0.25 \mathrm{mg} \mathrm{L}^{-1}$ 이다. 다음으로, Pseudomonas aeruginosa에 대한 독성효과가 가 장 큰 중금속은 카드뮴이며 가장 적은 중금속은 비소인 것 을 확인하였으며, 중금속으로 인한 Pseudomonas aeruginosa 의 $\mathrm{IC}_{50}$ 은 $\mathrm{Cu} 4.45 \mathrm{mg} \mathrm{L}^{-1}$, Cd $0.16 \mathrm{mg} \mathrm{L}^{-1}$, As $18.51 \mathrm{mg} \mathrm{L}^{-1}$, Zn $2.34 \mathrm{mg} \mathrm{L}^{-1}$ 이다. 마지막으로, Bacillus subtilis에 대한
독성효과가 가장 큰 중금속은 앞의 두 미생물과 마찬가지로 카드뮴이고 가장 적은 중금속은 비소인 것을 확인할 수 있 었으며, 중금속으로 인한 Bacillus subtilis의 $\mathrm{IC}_{50}$ 은 $\mathrm{Cu} 3.81 \mathrm{mg}$ $\mathrm{L}^{-1}$, Cd $0.18 \mathrm{mg} \mathrm{L}^{-1}$, As $11.31 \mathrm{mg} \mathrm{L}^{-1}$, Zn $0.47 \mathrm{mg} \mathrm{L}^{-1}$ 이다.

중금속처리에 따른 Bacillus sp. 3434 BRRJ의 인 제 거율 중금속 처리에 따른 Bacillus sp. $3434 \mathrm{BRRJ}$ 의 인 제거율을 확인한 결과 (Table 2) 모든 중금속 농도가 증가할

Table 1. Summary of median inhibitory concentrations of PAOs.

\begin{tabular}{cccc}
\hline \hline $\begin{array}{c}\text { Toxic } \\
\text { subastance }\end{array}$ & $\begin{array}{c}\text { Median Inhibition } \\
\text { Concentration }\left(\mathrm{IC}_{50}\right) \text { of } \\
\text { Bacillus sp. }\end{array}$ & $\begin{array}{c}\text { Median Inhibition } \\
\text { Concentration }\left(\mathrm{IC}_{50}\right) \text { of }\end{array}$ & $\begin{array}{c}\text { Median Inhibition } \\
\text { Concentration }\left(\mathrm{IC}_{50}\right)\end{array}$ \\
of $\left(\mathrm{mg} \mathrm{L}^{-1}\right)$ & $\begin{array}{c}\text { Pseudomonas } \\
\text { Bacruginosa }\left(\mathrm{mg} \mathrm{L}^{-1}\right)\end{array}$ & Bacillus subtilis $\left(\mathrm{mg} \mathrm{L}^{-1}\right)$ \\
\hline $\mathrm{Cu}$ & 8.07 & 4.45 & 3.81 \\
$\mathrm{As}$ & 0.18 & 0.16 & 0.18 \\
$\mathrm{Zn}$ & 73.62 & 18.51 & 11.31 \\
\hline
\end{tabular}

Table 2. Removal efficiencies of $\mathrm{P}$ by Bacillus sp. 3434 BRRJ in relation to heavy metals

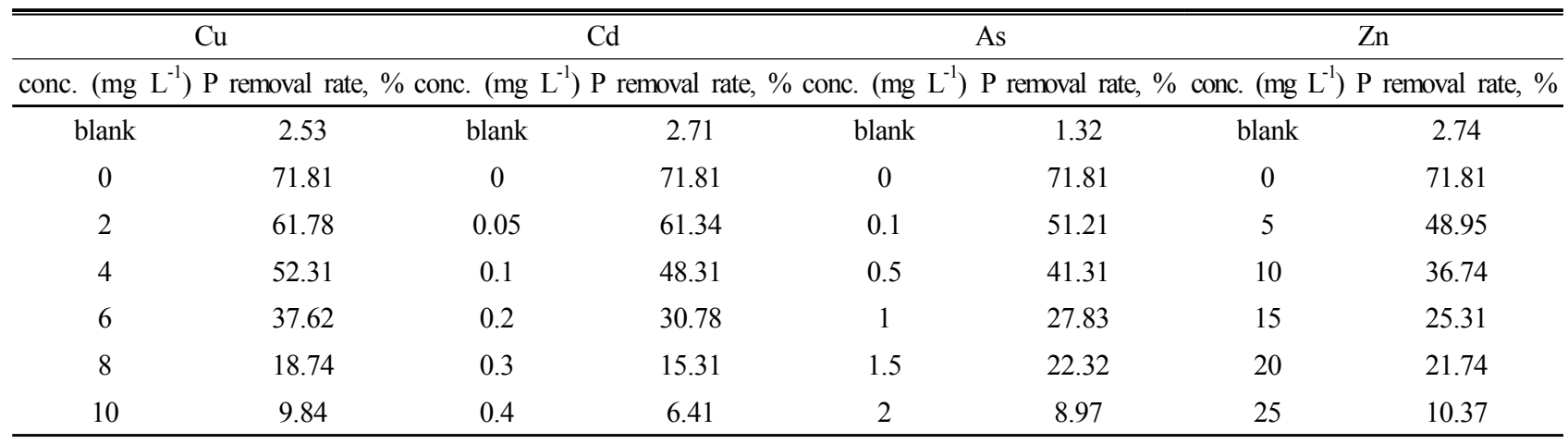


수록 인 제거율은 감소하는 것으로 나타났다. 구리의 경우 구리를 $2 \mathrm{mg} \mathrm{L}^{-1}$ 로 처리한 배지에서는 $91.9 \%$ 의 제거율을 보 여 중금속을 처리하지 않은 배지의 인 제거율 $93.1 \%$ 와 거의 같았다. 미생물 생장이 가장 크게 감소한 처리구인 $8 \mathrm{mg} \mathrm{L}^{-1}$ 과 $10 \mathrm{mg} \mathrm{L}^{-1}$ 에서는 인 제거율이 $30 \%$ 부근으로 나타났다. 카드뮴은 blank에서 인 농도의 변화가 없었으며 최저농도 의 카드뮴을 처리한 $0.05 \mathrm{mg} \mathrm{L}^{-1}$ 에서 인 제거율이 무처리구 에 비해 인 제거율이 거의 감소하지 않은 반면, $0.2 \mathrm{mg} \mathrm{L}^{-1}$ 이상의 카드뮴을 처리한 처리구는 무처리구에 비해 인 제거 율이 반 이상이 줄어들었다. 아연의 경우 최저농도의 처리 구인 $0.1 \mathrm{mg} \mathrm{L}^{-1}$ 에서도 $62.2 \%$ 로 인 제거율이 감소하였다. 중금속 아연 처리 시 대체로 무처리구에 비해 크게 감소한 인 제거율을 보였으며 무처리구에 비하여 인 제거율이 $50 \%$ 로 감소된 농도는 $0.1-0.5 \mathrm{mg} \mathrm{L}^{-1}$ 사이로 $\mathrm{IC}_{50}$ 값과 유사한 값을 가졌다. 비소의 경우 역시 중금속 처리 농도가 증가할 수록 인 제거율이 감소하는 것을 확인 할 수 있었으며 10 $\mathrm{mg} \mathrm{L} \mathrm{L}^{-1}$ 이상으로 처리하였을 때 인 제거율이 급격히 감소하 는 것을 확인할 수 있었다.

\section{중금속처리에 따른 Pseudomonas aeruginosa의 인 제}

거율 중금속 처리에 따른 Pseudomonas aeruginosa의 인 제거율 측정 결과 (Table 3), 처리한 중금속 농도가 증가할 수록 인 제거율은 감소하는 경향을 보였다. 구리의 농도에 따른 인제거율 확인 결과, 최저농도로 처리한 $2 \mathrm{mg} \mathrm{L}^{-1}$ 에서
$61.8 \%$ 로 나타났고, 최고농도로 처리한 $10 \mathrm{mg} \mathrm{L}^{-1}$ 에서는 $9.9 \%$ 로 매우 크게 감소한 것을 확인할 수 있었다. 카드뮴의 경우 는 $0.2 \mathrm{mg} \mathrm{L}^{-1}$ 에서 무처리구의 절반 정도의 인 제거율을 보 였다. 또한 가장 고농도인 $0.4 \mathrm{mg} \mathrm{L}^{-1}$ 에서 $6.4 \%$ 로 인 제거 율이 가장 낮게 측정되었다. 아연 또한 마찬가지로 최저농 도인 $0.1 \mathrm{mg} \mathrm{L}^{-1}$ 에서 인제거율이 $49.0 \%$ 로 무처리구에 비해 급격히 줄어들었으며 최고농도인 $2 \mathrm{mg} \mathrm{L}^{-1}$ 에서는 $10.4 \%$ 의 인 제거율을 보였다. 비소의 경우 5-20 mg L $\mathrm{L}^{-1}$ 처리구는 무 처리구에 비해 인 제거율 감소량이 적었으나, 최고농도인 $25 \mathrm{mg} \mathrm{L}^{-1}$ 처리구에서 인 제거율이 급격히 저하되는 것을 확인할 수 있었다.

\section{중금속 처리에 따른 Bacillus subtilis의 인 제거율} 중금속 처리에 따른 Bacillus subtilis의 인 제거율 측정 결 과 (Table 4), 앞의 두 미생물과 마찬가지로 처리한 중금속 의 농도가 증가할수록 인 제거율은 감소한다는 결과를 얻었 다. 구리의 경우 Bacillus subtilis와 구리를 모두 처리하지 않은 배지 내의 인 농도의 변화는 크게 일어나지 않았으며, 구리를 $1 \mathrm{mg} \mathrm{L}^{-1}$ 로 처리한 배지에서는 $62.9 \%$ 의 제거율을 보 여 중금속을 처리하지 않은 배지와 비슷하게 나타났다. 미 생물의 생장이 적게 이루어진 처리구인 $4 \mathrm{mg} \mathrm{L}^{-1}$ 과 $5 \mathrm{mg} \mathrm{L}^{-1}$ 에서는 인 제거율이 각각 $25.2 \%, 19.3 \%$ 로 나타났다. 카드뮴 의 경우, 무처리구에서 $65 \%, 0.05 \mathrm{mg} \mathrm{L}^{-1}$ 에서 무처리와 크 게 차이가 나지 않는 $56.6 \%$ 의 인 제거율을 보였으며, 0.4

Table 3. Removal efficiencies of P by Pseudomonas aeruginosa in relation to heavy metals

\begin{tabular}{|c|c|c|c|c|c|c|c|}
\hline \multicolumn{2}{|c|}{$\mathrm{Cu}$} & \multicolumn{2}{|c|}{$\overline{\mathrm{Cd}}$} & \multicolumn{2}{|c|}{ As } & \multicolumn{2}{|c|}{$\mathrm{Zn}$} \\
\hline \multicolumn{8}{|c|}{ conc. $\left(\mathrm{mg} \mathrm{L}^{-1}\right) \mathrm{P}$ removal rate, $\%$ conc. $\left(\mathrm{mg} \mathrm{L}^{-1}\right) \mathrm{P}$ removal rate, $\%$ conc. $\left(\mathrm{mg} \mathrm{L}^{-1}\right) \mathrm{P}$ removal rate, $\%$ conc. $\left(\mathrm{mg} \mathrm{L}^{-1}\right) \mathrm{P}$ removal rate, $\%$} \\
\hline blank & 2.53 & blank & 2.71 & blank & 1.32 & blank & 2.74 \\
\hline 0 & 93.12 & 0 & 93.12 & 0 & 93.12 & 0 & 93.12 \\
\hline 2 & 91.83 & 0.05 & 90.94 & 20 & 84.88 & 0.1 & 62.23 \\
\hline 4 & 86.31 & 0.1 & 85.71 & 40 & 53.65 & 0.5 & 37.91 \\
\hline 6 & 36.65 & 0.2 & 61.60 & 60 & 21.62 & 1 & 30.46 \\
\hline 8 & 31.67 & 0.3 & 39.41 & 80 & 14.60 & 1.5 & 24.05 \\
\hline 10 & 30.69 & 0.4 & 30.48 & 100 & 14.01 & 2 & 16.20 \\
\hline
\end{tabular}

Table 4. Removal efficiencies of $P$ by Bacillus subtilis in relation to heavy metals

\begin{tabular}{|c|c|c|c|c|c|c|c|}
\hline \multicolumn{2}{|c|}{$\mathrm{Cu}$} & \multicolumn{2}{|c|}{$\mathrm{Cd}$} & \multicolumn{2}{|c|}{ As } & \multicolumn{2}{|c|}{$\mathrm{Zn}$} \\
\hline \multicolumn{8}{|c|}{ conc. $\left(\mathrm{mg} \mathrm{L}^{-1}\right) \mathrm{P}$ removal rate, $\%$ conc. $\left(\mathrm{mg} \mathrm{L}^{-1}\right) \mathrm{P}$ removal rate, \% conc. $\left(\mathrm{mg} \mathrm{L}^{-1}\right) \mathrm{P}$ removal rate, $\%$ conc. $\left(\mathrm{mg} \mathrm{L}^{-1}\right) \mathrm{P}$ removal rate, $\%$} \\
\hline blank & 2.41 & blank & 2.84 & blank & 1.67 & blank & 3.07 \\
\hline 0 & 65.31 & 0 & 65.31 & 0 & 65.31 & 0 & 65.31 \\
\hline 2 & 62.09 & 0.05 & 56.58 & 0.1 & 59.01 & 5 & 58.85 \\
\hline 4 & 51.01 & 0.1 & 47.36 & 0.5 & 50.29 & 10 & 50.11 \\
\hline 6 & 37.21 & 0.2 & 28.54 & 1 & 32.52 & 15 & 32.18 \\
\hline 8 & 25.20 & 0.3 & 14.02 & 1.5 & 18.82 & 20 & 18.54 \\
\hline 10 & 19.26 & 0.4 & 7.63 & 2 & 12.78 & 25 & 12.47 \\
\hline
\end{tabular}


$\mathrm{mg} \mathrm{L}^{-1}$ 처리구에서 $7.6 \%$ 의 가장 낮은 인 제거율을 보였다. 비소는 다른 중금속들에 비해 독성이 상대적으로 약해서 높 은 농도에서 실험이 실시된 것을 제외하고 앞의 두 중금속 들과 같은 경향을 보였다. 가장 낮은 인 제거율을 보인 것은 가장 높은 농도인 $100 \mathrm{mg} \mathrm{L}^{-1}$ 의 비소 처리구의 $12.8 \%$ 이다. 아연 역시 앞의 중금속들과 마찬가지로 아연 농도가 높아짐 에 따라 인 제거율은 감소하는 경향을 보였다. 가장 낮은 인 제거율을 보인 것은 $0.4 \mathrm{mg} \mathrm{L}^{-1}$ 의 가장 높은 농도의 아연을 처리한 처리구에서 보인 $12.5 \%$ 이다.

\section{Discussion}

중금속 농도에 따른 Bacillus sp. 3434 BRRJ, Pseudomonas aeruginosa, Bacillus subtilis의 생장과 인 제거율에 대한 중 금속의 독성평가 실시 결과, Bacillus sp. 3434 BRR, Pseudomonas aeruginosa 및 Bacillus subtilis와 같은 PAOs에 속하는 미 생물의 생장 및 인 제거율은 첨가된 중금속들에 의해 영향 을 받는다는 것을 확인할 수 있었다. 본 실험은 $\mathrm{pH}$ 가 7.0, $30^{\circ} \mathrm{C}$, 호기조건, 탄소원으로 glucose를 공급한 조건에서 진 행되었으며, 이러한 환경 조성은 Kim et al.(2012)의 연구결 과 중 생물학적 인 제거 공정에 쓰이는 PAOs의 인 제거율은 $20^{\circ} \mathrm{C}-37^{\circ} \mathrm{C}$ 의 비교적 높은 온도, $6.5-8.0$ 사이의 $\mathrm{pH}$ 조건 에서 인 제거율이 증가한다는 내용을 바탕으로 하였다.

본 실험은 세가지 종류의 미생물인 Bacillus sp. 3434 BRRJ 와 Pseudomonas aeruginosa, Bacillus subtilis에 대한 4가 지 중금속 $(\mathrm{Cu}, \mathrm{As}, \mathrm{Zn}, \mathrm{Cd})$ 의 독성에 따른 미생물 생장 저 해효과 비교를 목적으로 실시되었으며, 각 중금속간의 독성 비교는 반 생장 농도인 $\mathrm{IC}_{50}$ 값을 이용하여 실시하였다. 비교 결과, Bacillus sp. 3434 BRRJ, Pseudomonas aeruginosa 모두 카드뮴〉 아연> 구리〉 비소 순으로 강한 독성효과를 보 였으며, 이는 Kim et al. (2010)의 연구결과인 Pseudomonas $s p$. 에 대한 중금속의 독성효과 비교 결과와 유사하다. 실험 에 이용한 3 종의 미생물들은 공통적으로 비소의 독성에 가 장 강한 내성을 보였으며, 카드뮴과 아연에 대해서는 상대 적으로 민감한 경향을 갖는 것을 확인할 수 있었다. Bacillus sp. 3434 BRR와 Pseudomonas aeruginosa, Bacillus subtilis 모두 카드뮴의 독성에 가장 민감한 반면, 비소의 독성효과에 대해서는 가장 강한 내성을 보였다. 이는 Yoo et al.(2011) 의 중금속이 미생물에 미치는 독성효과에 관한 연구 결과와 유사하였다. 한편, 본 실험 결과 중 주목할 만한 것은 Bacillus $s p .3434 B R R J$ 의 비소 독성에 대한 내성이 다른 실험 미생 물들보다 월등히 뛰어났다는 점이다. Pseudomonas aeruginosa 의 비소에 대한 $\mathrm{IC}_{50}$ 은 $18.51 \mathrm{mg} \mathrm{L}{ }^{-1}$, Bacillus subtilis의 $\mathrm{IC}_{50}$ 은 $11.31 \mathrm{mg} \mathrm{L}^{-1}$ 인 반면 Bacillus sp 3434 BRRJ는 73.62 $\mathrm{mg} \mathrm{L}{ }^{-1}$ 로 앞의 두 미생물들에 비해 약 4-6배 정도 강한 내 성을 가졌다. 실험 결과, 미생물에 첨가되는 중금속의 농도
가 증가할수록 인 제거율이 감소하는 경향을 확인할 수 있 었으며, 이는 Kim et al. (2010)의 연구결과와 유사한 경향성 을 보인다. 각 미생물의 중금속을 첨가하지 않았을 때의 인 제거율은 Bacillus sp. 3434 BRRJ (93.12\%) > Pseudomonas aeruginosa (71.81\%) > Bacillus subtilis (65.31\%)의 순 이었다.

\section{Conclusions}

본 실험 결과를 통해 미생물의 생장과 인 제거에 단일 중 금속 농도에 따른 중금속의 독성효과를 확인할 수 있었으나 실제 폐수와 같은 여러 종류의 독성물질들이 복합적으로 존 재하는 환경에서의 실험은 실시하지 않았으므로, 이에 대한 연구가 필요하다. 본 연구는 앞으로 실제 폐수에서 실시될 생물학적 인 제거 공정 연구의 유용한 기초자료로 쓰일 수 있을 것이라 사료된다. 앞으로 실시될 연구는 실제 폐수 환 경과 유사한 환경조건에서 실시되어야 하며, 중금속 또한 단일 중금속의 처리보다는 여러 종류의 중금속들을 혼합 처 리한 조건에서 실시되어야 할 것이다.

실험 결과, Bacillus sp. 3434 BRRJ는 다른 2종의 미생 물들에 비해 뛰어난 인 제거율과 비소 독성 내성을 확인하 였으므로, 이에 대한 프로테오믹스 연구가 실시되어야 할 것 이라 사료된다. 단백질 분석을 통해 Bacillus sp. 3434 BRRJ 인 제거 작용기작 규명과 다른 PAOs들에 비해 강한 비소 독 성 내성의 원인이 되는 단백질과 그 역할에 관한 연구 실시 가 필요하다고 사료된다.

\section{References}

Hammaini, A., F. Gonzalez, A. Ballester, M.L. Blazquez, and J.A. Munoz. 2007. Biosorption Of Heavy Metals By Activated Sludge And Their Desorption Characteristics. J. Of Environ. Management. 84:419-426.

Arvin. 1985. Observations Supporting Phosphate Removal By Biologically Mediated Chemical Precipitation : A review. water sci. technol. 15:43-63.

Bang, S. W., Y.K. Choi, and M.S. Han, 2001. Recent Development Of Removal And Treatment Of Toxic Heavy Metals By Microorganisms. Environ. biol. p. 96.

Boswell, C.D., R.E. Dick, and L.E. Macskie, 1999. The Effect Of Heavy Metals And Other Environmental Conditions On The Anaerobic Phosphate Metabolism Of Acinetobacter johnsonii. Micrbiology. 145:1711-1720.

Chung, K.Y., S.S. Han, H.K. Kim, G.S. Choi, I.S. Kim, S.S. Lee, S.H. Woo, K.H. Lee, and J.J. Kim, 2006. Inhibitory Effect of the Selected Heavy Metals on the Growth of the Phosphorus Accumulating Microorganism, Acinetobacter sp. Korean J. Environ. Agri. 25(1):40-46.

Gabriel Bitton. 1999. Wastewater Microbiology. Wiley-liss. p. 
103.

Kim, H.J., R.B. You, S.S. Han, S.H. Woo, M.S. Lee, K.T. Baek, and K.Y. Chung, 2010. Effect of the Various Heavy Metals on the Growth and Phosphorus (P) Removal Capacity of the Phosphorus Accumulating Microorganism (Pseudomonas $s p$.). Korean J. Environ. Agri. 29(2):189-196.

Kim, H.J., S.E. Lee, H.K. Hong, D.H Kim, J.W. An, J.S. Choi, J.H. Nam, M.S. Lee, S.H. Woo, and K.Y. Chung, 2012. Phosphorus Removal Characteristic by Bacteria Isolated from Industrial Wastewater. Korean J. Environ. Agri. 31(2):185-191. Meganck, M.T.J. and G.M Faup. 1988. Enhanced Biological Phosphorus Removal From Wastewater Biotreament System. D.L wise. pp. 111-203.

Mino, T., M.C. Van loosdrecht, and J.J. Heijuen, 1998. Microbiology And Biochemistry Of The Enhanced Biological Phosphorus Removal Process. Water Res. 37:409.

Strechan, M., J.R. Golecki, and G. Schon. 1990. Polyphosphate- accumulating bacteria from sewage plants with different processes for biological phosphorus removal. FEMS Microbiol. Ecol. 73:113-124.

Yan Liu, Yinguang Chen, Qi Zhou. 2007. Effect Of Initial pH Control On Enhanced Biological Phosphorus Removal From Wastewater Containing Acetic And Propionic Acids. Chemosphere. 66(1):123-129.

Yoo, R.B., H.J. Kim, S.E. Lee, M.S. Lee, S.H. Woo, J.S. Choi, K.T. Baek, and K.Y. Chung. 2011. Effects of Environmental Factors and Heavy Metals on the Growth and Phosphorus Removal of Alcaligenes sp. Korean J. Environ. Agri. 30(2):216-222.

Zafiri, C., M. Kornaros, and G. Lyberatos, 1999. Kinetic Modeling Of Biological Phosphorus Removal With A Pure Culture Of Acinetobactor sp. Under Aerobi, Anaerobic, And Transient Operating Conditions. Water Res. 33(12):2769-2788. 